\title{
TINJAUAN HUKUM TENTANG PELAKSANAAN PERJANJIAN JUAL BELI ONLINE MELALUI E-COMMERCE MENURUT PASAL 1320 KUHPERDATA
}

\author{
NAFA AMELSI TRIANTIKA, ELWIDARIFA MARWENNY, MUHAMMAD \\ HASBI \\ nafaamelsitriantika@gmail.com, elwidarifamarwenny@gmail.com, \\ muhammadhasbi@gmail.com \\ Program Studi Ilmu Hukum Universitas Dharma Andalas
}

\begin{abstract}
This research is motivated by the fact that the implementation of the online sale and purchase agreement is regulated based on article 1320 of the Civil Code regarding the legal terms of the agreement which contain the agreement of both parties, the ability to act, the object of the agreement and the existence of a halacausa. The aim of this study is try to find out 1.) what is the form of legal arrangements for online sale and purchase agreements through e-commerce and 2) how is the form of legal protection for buyers in conducting online buying and selling through $e$ commerce if the seller defaults. The method that was used in this study is a qualitative method with a normative juridical approach. The conclusion of the study is the regulation of the implementation of online trading through e-commerce regulated by Article 1320 of the Civil Code regarding the legal terms of the agreement namely the agreement of both parties, the ability to act, the object of the agreement and the existence of a hala, and legal protection against the buyer if the seller defaults are protected by Act Number 8 of 1999 concerning consumer protection and Act Number 19 of 2019 concerning ITE.
\end{abstract}

Keywords: Agreement, E-commerce, Buy and Sell.

Abstrak: Penelitian ini dilatar belakangi karena pelaksanaan perjanjian jual beli online diatur berdasarkan pasal 1320 KUHPerdata tentang syarat sah perjanjian yang berisi adanya kesepakatan kedua belah pihak, adanya kecakapan bertindak, adanya objek perjanjian serta adanya causa yang halal. Berdasarkan hal tersebut penulis tertarik melaksanakan penelitian ini, adapun rumusan masalahnya 1.bagaimana bentuk pengaturan hukum terhadap perjanjian jual beli online melalui e-commerce dan 2.bagaimana bentuk perlindungan hukum terhadap pembeli dalam pelaksanaan jual beli online melalui e-commerce jika penjual melakukan wanprestasi. Untuk menjawab hal tersebut penelitian ini menggunakan metode kualitatif dengan pendekatan yuridis normatif. Kesimpulan dari penulisan skripsi ini yaitu pengaturan pelaksanaan jual beli online melalui e-commerce diatur pasal 1320 KUHPerdata tentang syarat sah perjanjian yaitu adanya kesepakatan kedua belah pihak, adanya kecakapan bertindak, adanya objek perjanjian dan adanya causa yang halal sedangkan perlindungan hukum terhadap pembeli jika penjual melakukan wanprestasi diatur oleh Undang-Undang Nomor 8 Tahun 1999 tentang perlindungan konsumen dan Undang-Undang Nomor 19 Tahun 2019 tentang ITE.

Kata kunci: Perjanjian, E-commerce, Beli dan Jual.

\section{A. Pendahuluan}

Teknologi informasi dan komunikasi di era globalisasi memiliki peran yang strategis karena membuka dunia tanpa batas, jarak, ruang, dan waktu, sehingga berdampak pada peningkatan produktivitas dan efisiensi. Pengaruh globalisasi dengan penggunaan sarana teknologi informasi dan komunikasi telah mengubah pola atau cara E-ISSN: 2657-0300 Lembaga Penelitian dan Penerbitan Hasil Penelitian Ensiklopedia 119 P-ISSN: 2657-0319 
hidup masyarakat, dan berkembang dalam tatanan kehidupan baru serta dapat mendorong terjadinya perubahan sosial, ekonomi, budaya, keamanan, serta penegakan hukum, hal ini dapat dilihat dari perkembangan media internet yang sangat pesat saat ini (Siswanto Sunarso, 2009). Internet sebagai media informasi dan komunikasi elektronik telah banyak dimanfaatkan untuk berbagai kegiatan, antara lain yaitu untuk perdagangan, serta terdapat banyak manfaat salah satunya transaksi lebih mudah, cepat, praktis dan harga yang lebih terjangkau, sehingga perdagangan atau bisnis menjadi lebih efisien. Kegiatan perdagangan dengan memanfaatkan media internet ini dikenal dengan istilah electronic commerce, atau disingkat e-commerce yang merupakan kegiatan membeli atau menjual suatu barang atau jasa secara elektronik yang dilakukan melalui jaringan internet.

E-commerce dipercaya memiliki potensi yang sangat besar untuk mengembangkan perdagangan atau bisnis didalam dunia maya melalui media internet yang terus berkembang. Jual beli merupakan salah satu jenis perjanjian yang diatur dalam KUHPerdata, dimana pihak yang satu mengikatkan dirinya untuk menyerahkan suatu kebendaan dan pihak yang lain untuk membayar harga yang telah dijanjikan. Jual beli online merupakan pelaksanaan jual beli yang menggunakan teknologi seperti internet. Dalam perjanjian jual beli adanya hak dan kewajiban dari penjual dan pembeli karena penjual dan pembeli telah melakukan persetujuan. Pelaksanaan jual beli online tidak lepas dari masalah perjanjian, karena pelaksanaan ini dilakukan tanpa ada pertemuan antara penjual dan pembeli sehingga yang menjadi dasar dalam jual beli adalah kepercayaan yang ada antara penjual dan pembeli. Oleh karena itu, perjanjian jual beli yang terjadi diantara para pihak dilakukan secara elektronik hanya mendasarkan pada asas kepercayaan karena tidak ada berkas perjanjian seperti pada pelaksanaan jual beli pada tatap muka langsung. Lazimnya pelaksanaan jual beli online belakangan ini membuat pembeli sering lupa bahwa pelaksanaan jual beli online tidak luput dari bahaya yang dapat ditimbulkan seperti perbuatan wanprestasi kepada pembeli karena pelaku usaha tidak dapat mempertanggung jawabkan janjinya. Dalam perjanjian dengan tatap muka langsung, jika pelaku usaha tidak dapat mempertanggung jawabkan janji yang telah disepakati, maka dapat digugat oleh pihak yang dirugikan. Menurut Pasal 1320 KUHPerdata mengatur bahwa perjanjian harus memenuhi syarat sahnya perjanjian yaitu sepakat mereka yang mengikatkan dirinya, kecakapan untuk membuat suatu perjanjian, suatu hal tertentu dan suatu sebab yang halal. Apabila sudah memenuhi empat syarat sahnya perjanjian, maka perjanjian sudah dapat dikatakan sah dan mengikat para pihak namun bagaimana dengan perjanjian online dimana pihak yang berjanji tidak bertatap muka langsung.

\section{B. Metodologi Penelitian}

Pendekatan masalah yang digunakan dalam penelitian ini adalah yuridis normatif dengan mempelajari bahan-bahan kepustakaan seperti, perundangan, jurnal dan pendapat para ahli baik secara offline maupun online. Sifat penelitian adalah deskriptif yaitu suatu penelitian yang bertujuan untuk memberikan gambaran penjelasan secara konkrit tentang keadaan objek dan masalah yang diteliti dan mengambil kesimpulan secara umum, sehingga dengan adanya penelitian ini diharapkan dapat memperoleh gambaran yang menyeluruh, lengkap dan sistematis tentang objek yang diteliti (Soerjono Soekanto, 2009). 


\section{Hasil Dan Pembahasan}

\section{Bentuk Pengaturan Hukum terhadap Perjanjian Jual Beli Online melalui E- commerce}

Aturan mengenai transaksi jual beli online masih mengacu pada syarat sah perjanjian pada Pasal 1320 KUHPerdata. Dalam perjanjian jual beli online melalui $e$ commerce yang menjadi subjek jual beli melalui e-commerce adalah pelaku usaha yang menjual barang dan pembeli sebagai konsumen yang membayar harga barang yang telah disepakati, jual beli online hanya dilandasi kepercayaan antara penjual dan pembeli (Andi Tentri Ajeng P, 2017). Adapun yang menjadi objek dalam jual beli online adalah barang atau jasa yang telah dibeli konsumen, kadangkala harga barang atau jasa tersebut tidak dapat dilihat langsung oleh pembeli karena pelaksaan jual beli dilakukan secara online sehingga sangat rentan terjadinya penipuan.

Syarat sah perjanjian pada Pasal 1320 KUHPerdata sebagai berikut terdiri dari adanya kesepakatan kedua belah pihak, adanya kecakapan bertindak, adanya objek yang diperjanjikan dan adanya causa yang halal.

1. Adanya kesepakatan kedua belah pihak

Kesepakatan menurut kamus Bahasa Indonesia adalah setuju, jadi maksud dari Kesepakatan merupakan persesuaian pernyataan kehendak antara satu orang atau lebih dengan pihak lainnya. Keberadaan dalam suatu unsur kesepakatan E-commerce diukur melalui pembeli yang mengakses dan menyetujui penawaran melalui internet atau online. Persetujuan yang diberikan oleh pembeli ini menjadi dasar dari kesamaan kehendak para pihak, sehingga kesepakatan dalam kontrak elektronik lahir. Berdasarkan kesepakatan menurut pasal 1320 KUHPerdata dilakukan dengan secara tertulis atau secara langsung disertai tanda tangan antara penjual dan pembeli, namun pada kesepakatan jual beli online dilakukan secara tidak tertulis atau secara tidak langsung bertatap muka antara penjual dan pembeli hanya dilakukan melalui chat lewat media internet. Sedangkan dalam KHUPerdata pasal 1866, yang termasuk kedalam alat bukti adalah bukti tertulis, bukti saksi, persangkaan, pengakuan dan sumpah. Dalam jual beli konvensional perjanjian merupakan bukti tertulis sedangkan dalam jual beli online alat bukti yang berbentuk chat yang dapat di cetak dengan bentuk kertas sudah termasuk kedalam bentuk dokumen dalam perjanjian (hukumonline.com). Pendapat ini, juga didukung oleh Undang-Undang Nomor 19 Tahun 2016 Tentang ITE Pasal 1 Ayat (4) yang menyatakan bahwa Dokumen elektronik adalah setiap informasi elektronik yang dibuat, diteruskan, dikirimkan, diterima, atau disimpan dalam bentuk analog, digital, elektromagnetik, optikal atau sejenisnya yang dapat dilihat, ditampilkan, dan/atau didengar melalui komputer atau sistem elektronik, termasuk tetapi tidak terbatas pada tulisan, suara, gambar, peta, rancangan, foto atau sejenisnya, huruf, tanda, angka, kode akses, simbol atau perforasi yang memiliki makna atau arti atau dapat dipahami oleh orang yang mampu memahaminya. Sedangkan menurut Pasal 5 Undang-Undang Nomor 19 Tahun 2016 Tentang ITE mengatakan bahwa :

(1) Informasi Elektronik dan/atau Dokumen Elektronik dan/atau hasil cetaknya merupakan alat bukti hukum yang sah.

(2) Informasi Elektronik dan/atau Dokumen Elektronik dan/atau hasil cetaknya sebagaimana dimaksud pada ayat (1) merupakan perluasan dari alat bukti yang sah sesuai dengan Hukum Acara yang berlaku di Indonesia.

(3) Informasi Elektronik dan/atau Dokumen Elektronik dinyatakan sah apabila menggunakan sistem elektronik sesuai dengan ketentuan yang diatur dalam Undang-undang ini. 
(4) Ketentuan mengenai Informasi elektronik dam/atau Dokumen Elektronik sebagaimana dimaksud pada ayat (1) tidak berlaku untuk:

a. Surat yang menurut Undang-undang harus dibuat dalam bentuk tertulis

b. Surat beserta dokumennya yang menurut Undang-undang harus dibuat dalam bentuk akta notaril atau akta yang dibuat oleh pejabat pembuat akta.

\section{Adanya Kecakapan Bertindak}

Kecakapan bertindak merupakan kecakapan atau kemampuan untuk melakukan perbuatan hukum. Perbuatan hukum yang dimaksud adalah perbuatan yang akan menimbulkan akibat hukum. Orang-orang yang akan mengadakan perjanjian haruslah orang-orang yang cakap dan wewenang untuk melakukan perbuatan hukum sebagaimana yang ditentukan oleh Undang-undang. Kecakapan adalah sanggup melakukan sesuatu serta mampu dan dapat mempunyai kemampuan untuk mengerjakan sesuatu. Pada dasarnya, semua orang dianggap tahu hukum kecuali orang yang tidak cakap hukum yang tertuang dalam Pasal 1330 KUHPerdata yaitu: anak yang belum dewasa, orang yang ditaruh dibawah pengampuan, perempuan yang telah kawin dalam hal-hal yang ditentukan Undang-undang dan pada umumnya semua orang yang oleh Undang-undang dilarang untuk membuat persetujuan tertentu.

Dalam pelaksanaan jual beli online melalui e-commerce orang yang belum cakap melakukan perjanjian dianggap sah apabila tidak merugikan kedua belah pihak (researchgate.net) karena jika dikaitkan dengan unsur kecakapan dalam KUHPerdata dan pelaksanaan jual beli online sulit untuk diketahui apakah seseorang tersebut cakap hukum atau tidak.

3. Adanya Objek Perjanjian

Prestasi merupakan apa yang menjadi kewajiban debitor dan apa yang menjadi hak kreditor. Prestasi ini terdiri dari perbuatan positif dan negatif yaitu memberikan sesuatu, berbuat sesuatu dan tidak berbuat sesuatu. Misalnya jual beli barang online, yang menjadi prestasi atau pokok perjanjian adalah menyerahkan hak milik atas barang online itu dan menyerahkan atau mentransfer uang harga dari pembelian barang online itu. Dalam jual beli konvensional jelas barang yang ditawarkan penjual dapat dilihat langsung oleh pembeli serta penyerahannya juga dapat dilakukan secara langsung. Sedangkan dalam transaksi melalui online pembeli hanya bisa melihat barang dalam bentuk foto atau gambar. Pembeli bisa melihat barang apabila telah selesai melakukan penawaran dan kesepakatan kepada penjual, baru penjual bisa mengirim barang yang ditawarkan pembeli, jadi jual beli secara konvensional dan secara online harus memenuhi syarat tertentu.

Dalam pelaksanaan jual beli online sering terjadi wanprestasi karena penjual dan pembeli tidak bertatap muka secara langsung namun bertransaksi melalui media internet dan pembeli tidak bisa melihat langsung barang yang akan dibeli seperti barang yang dipesan tidak sesuai dengan gambar atau foto yang dipajang penjual melalui media elektronik (Herniwati, 2015) sehingga konsumen dirugikan. Hal ini merupakan perbuatan wanprestasi yang merugikan konsumen.

4. Adanya Causa yang Halal

Dalam Pasal 1320 KUHPerdata tidak dijelaskan pengertian causa yang halal hanya disebutkan causa yang terlarang dalam Pasal 1337 KUHPerdata. Suatu sebab adalah terlarang apabila bertentangan dengan Undang-undang, kesusilaan dan ketertiban umum, seperti yang terjadi sekarang dalam jual beli konvensional maupun jual beli 
online masih banyak yang melakukan perbuatan melawan hukum menjual barang yang dilarang, menjual barang yang bertentangan dengan hukum seperti menjual obat-obatan yang terlarang, minuman berakohol, penjual dan pembeli melakukan wanprestasi (H. Bahiyah, 2016). Menurut hukum sepanjang memenuhi pasal 1320 KUHPerdata, dimana syarat sah pertama dan kedua disebut syarat subjektif karena menyangkut pihak-pihak yang mengadakan perjanjian sedangkan syarat ketiga dan keempat merupakan syarat objektif karena menyangkut objek perjanjian. Apabila syarat pertama dan kedua tidak terpenuhi, maka perjanjian dapat dibatalkan. Syarat ketiga dan keempat tidak terpenuhi, maka perjanjian itu batal demi hukum. Artinya bahwa dari semula perjanjian itu dianggap tidak ada.

Undang-Undang Nomor 7 Tahun 2014 tentang perdagangan Pasal 65 tentang perdagangan melalui sistem elektronik menjelaskan: 1) Setiap pelaku usaha yang memperdagangkan barang dan/atau jasa dengan mengguanakan sistem elektronik wajib menyediakan data dan/atau informasi secara lengkap dan benar; 2) Setiap pelaku usaha dilarang memperdagangkan barang dan/atau jasa dengan menggunakan sistem elektronik yang tidak sesuai dengan data dan/atau informasi secara lengkap dan benar; 3) Penggunaan sistem elektronik wajib memenuhi ketentuan yang diatur dalam Undang-undang Informasi dan Transaksi Elektronik; 4) Data dan/atau informasi secara lengkap dan benar memuat; a. Identitas dan legalitas pelaku usaha sebagai produsen atau pelaku usaha distribusi; b. Persyaratan teknis barang yang ditawarkan; c. Persyaratan teknis atau kualifikasi jasa yang ditawarkan; d. Harga dan cara pembayaran barang dan/atau jasa dan e. Cara penyerahan barang; 5) Dalam hal terjadi sengketa terkait dengan transaksi dagang melalui sistem elektronik, orang atau badan usaha yang mengalami sengketa tersebut melalui pengadilan atau melalui mekanisme penyelesaian sengketa lainnya; dan 6) Setiap pelaku usaha yang memperdagangkan barang dan/atau jasa dengan menggunakan sistem elektronik yang tidak menyediakan data dan/atau informasi secara lengkap dan benar dikenai sanksi administratif berupa pencabutan izin.

Akhir-akhir ini telah banyak bermunculan berbagai commerce website dan berbagai portal diinternet di Indonesia yang menawarkan berbagai barang dan jasa kepada masyarakat atau konsumen Indonesia namun sampai sekarang Indonesia bukan saja belum memiliki undang-undang tentang e-commerce, bahkan rancangan Undangundangnyapun belum dimulai pembahasan dan pembuatannya (researchgate.net), apabila Indonesia tidak segera untuk menyusun Undang-undang tersebut, sedangkan transaksi e-commerce yang dilakukan oleh orang-orang Indonesia dengan toko-toko maya (virtual stores) semakin marak saja, maka dikhawatirkan sekali akan keamanan bagi para konsumen.

Dikarenakan belum adanya aturan perundangan yang mengatur transaksi perdagangan elekronik (e-commerce), maka dalam perdagangan di Indonesia, KUHPerdata yang menjadi dasar atau sumber dari perikatan untuk adanya kesepakatan melakukan pelaksanaan jual beli online yang selama ini telah digunakan sebagai dasar dari transaksi perdagangan konvensional. Aspek hukum perjanjian dalam perdagangan mengacu pada 2 prinsip kebebasan sebagai prinsip klasik hukum ekonomi internasional yaitu: a) Freedom of commerce atau kebebasan berniaga, niaga diartikan luas dari sekedar kebebasan berdagang. Jadi setiap negara memiliki kebebasan untuk berdagang dengan pihak atau negara manapun didunia; dan b) Freedom of Communication (kebebasan berkomunikasi) merupakan setiap negara memiliki kebebasan untuk melakukan transaksi perdagangan internasional. 
Kegiatan perdagangan di Indonesia termasuk dalam aspek hukum perdata dan sumbernya diatur dalan buku III KUHPerdata yaitu tentang perikatan yang secara umum dapat dijelaskan bahwa perdagangan terjadi karena adanya suatu kesepakatan antara para pihak dan kesepakatan tersebut diwujudkan dalam perjanjian dan menjadi dasar perikatan bagi para pihak. E-commerce dapat diantisipasi dengan adanya sistem pengamanan jaringan yang juga menggunakan kriptografi terhadap data dengan menggunakan sistem pengamanan dengan digital signature selain itu berfungsi sebagai suatu prosedur untuk melakukan kesepakatan dalam transaksi elektronik dari proses penawaran hingga kesepakatan yang dibuat para pihak.

\section{Bentuk Perlindungan Hukum terhadap Pembeli dalam Pelaksanaan Perjanjian Jual Beli Online melalui E-commerce Jika Penjual Melakukan Wanprestasi}

Perjanjian yang diwujudkan dalam bentuk perlindungan hukum jual beli terhadap konsumen sangat diperlukan karena dalam pelaksanaan jual beli online sering kali terjadi kecurangan (Niniek Suparni, 2009). Mengacu pada syarat sah perjanjian yaitu:

1) Adanya kesepakatan. Kesepakatannya dalam jual beli dengan tatap muka dilakukan secara tertulis atau secara langsung sedangkan kesepakatan jual beli online dilakukan secara tidak tertulis atau tidak langsung hanya dilakukan melalui chat. Dalam Undang-undang perlindungan konsumen tidak diatur namun kesepakatan melalui chat namun dalam Undang-Undang ITE kesepakatan melalui chat diatur dalam Pasal 1 Ayat (4);

2) Kecakapan bertindak, dalam jual beli online orang yang belum cakap melakukan perjanjian dianggap sah apabila tidak merugikan kedua belah pihak karena dikaitkan dalam KUHPerdata dan jual beli online sulit diketahui apakah seseorang cakap hukum atau tidak maka perlindungan hukum yang dapat digunakan dalam hal ini adalah pasal 4 dan 5 Undang-undang perlindungan konsumen tentang hak dan kewajiban konsumen;

3) Adanya objek perjanjian, dalam jual beli konvensional barang yang ditawarkan penjual dapat dilihat langsung oleh pembeli dan penyerahan barang juga dilakukan secara langsung, sedangkan jual beli online pembeli hanya bisa melihat barang dalam bentuk foto/gambar, sehingga rentan terjadi perbuatan wanprestasi. Perlindungan hukum dalam hal ini diatur dalam pasal 45 UndangUndang Perlindungan konsumen dan pasal 38 Undang-Undang ITE;

4) Adanya causa yang halal, Dalam Jual beli melalui konvensional mapun jual beli online banyak terjadi perbuatan melawan hukum seperti menjual barang yang dilarang, maka perbuatan ini termasuk kedalam pasal 8 Undang-Undang Perlindungan konsumen tentang perbuatan yang dilarang oleh pelaku usaha, maka perlindungan hukum terhadap konsumen dapat menggunakan pasal 47 Undang-Undang perlindungan konsumen dan pasal 38 Undang-Undang ITE tentang penyelesaian sengketa.

Kecurangan-kecurangan tersebut dapat menyangkut keberadaaan penjual maupun pembeli. Dalam kecurangan yang merugikan pembeli misalnya berbelanja di virtual store yang yang fiktif seperti barang yang harusnya dikirim oleh penjual tidak dikirimkan kepada pembeli, atau terjadi keterlambatan pengiriman yang berkepanjangan, terjadinya kerusakan atas barang yang dikirimkan atau barang yang dikirimkan cacat, apapun yang menyangkut purchase order dan pembayaran oleh 
pembeli disangkal oleh penjual kebenarannya, misalnya penjual hanya mengakui bahwa jumlah barang yang dipesan kurang dari yang tercantum didalam purchase order yang dikirimkan secara elektronik dan/atau harga per unit dari bidang yang dipesan oleh pembeli dikatakan lebih tinggi dari pada harga yang dicantumkan didalam purchase order.

Didalam jual beli melalui e-commerce pelaku usaha membuat acuan supaya pembeli yakin dan percaya untuk berbelanja online, maka pelaku usaha membuatnya seperti: 1) Mencantumkan logo pelaku usaha, pencantuman logo perusahaan dalam suatu website menandakan bahwa website tersebut benar-benar ada; dan 2) Mencantumkan alamat, pencantuman alamat pada website bertujuan agar memberitahu konsumen bahwa mereka benar-benar ada sehingga konsumen merasa aman untuk berbelanja.

Pelaku usaha dalam jual beli online menjadi salah satu faktor penting bagi pembeli, seperti halnya ketika pembeli ingin membeli suatu barang atau jasa yang diperlukan mencari validitas penjual, yang mana validitas penjual cakupannya luas seperti website terdaftar valid, penjual memiliki reputasi yang baik, dan produk atau jasa yang mereka tawarkan valid dan terdaftar. Maka sebelum melakukan jual beli online perlu dipastikan informasi tentang pelaku usaha. Apabila penjual tidak membuat acuan diatas kemungkinan penjual mudah untuk melakukan wanprestasi terhadap pembeli, jadi pembeli harus mendapat perlindungan hukum dari perbuatan penjual (Hillary Ayu Sekar Gusti, 2018).

Perlindungan hukum adalah memberikan pengayoman kepada hak asasi manusia yang dirugikan orang lain dan perlindungan tersebut diberikan kepada masyarakat agar mereka dapat menikmati semua hak-hak yang diberikan oleh hukum. Perlindungan hukum dapat dibagi menjadi 2 yaitu: 1) Perlindungan hukum preventif adalah perlindungan yang diberikan oleh pemerintah dengan tujuan untuk mencegah sebelum terjadinya pelanggaran. Peraturan perundang-undangan dengan maksud untuk mencegah suatu pelanggaran serta memberikan rambu-rambu atau batasan-batasan dalam melakukan suatu kewajiban; 2) Perlindungan hukum represif adalah perlindungan akhir berupa sanksi seperti denda, penjara dan hukuman tambahan yang diberikan jika sudah terjadi sengketa atau telah dilakukan suatu pelanggaran (http//digilib.unila.ac.id). Adapun perlindungan hukum memiliki tujuan untuk memberikan hak-hak masyarakat. Namun saat sekarang dalam jual beli online hak pembeli masih sering diabaikan oleh pelaku usaha misalnya pelaku usaha melakukan perbuatan wanprestasi. Perbuatan wanprestasi merupakan kelalaian karena tidak memenuhi perikatan yang dapat dipertanggung jawabkan, sedangkan menurut J.Satrio (2014) wanprestasi merupakan suatu peristiwa atau keadaan, dimana debitur tidak memenuhi kewajiban prestasi perikatannya dengan baik, dan debitur punya unsur salah atasnya, maka dalam perlindungan konsumen dapat dibedakan dalam dua aspek yaitu (Zulham, 2013): a) Perlindungan terhadap kemungkinan barang yang diserahkan kepada konsumen tidak sesuai dengan apa yang telah disepakati; dan b) Perlindungan terhadap diberlakukannya syarat-syarat yang tidak adil kepada konsumen.

Dimana konsumen harus dilindungi oleh hukum karena salah satu sifat dan tujuan hukum memberikan perlindungan kepada masyarakat harus diwujudkan dalam bentuk kepastian hukum menjadi hak konsumen yang diatur dalam Pasal 4 UndangUndang perlindungan konsumen tentang hak konsumen yang berisi: a) Hak atas kenyamanan, keamanan, dan keselamatan dalam mengkonsumsi barang dan/atau jasa; b Hak untuk memilih barang dan/atau jasa serta mendapatkan barang dan/atau jasa tersebut sesuai dengan nilai tukar dan kondisi serta jaminan yang dijanjikan; c) Hak E-ISSN: 2657-0300 Lembaga Penelitian dan Penerbitan Hasil Penelitian Ensiklopedia 125 P-ISSN: 2657-0319 
atas informasi yang benar, jelas dan jujur mengenai kondisi dan jaminan barang dan/atau jasa; d) Hak untuk didengar pendapat dan keluhannya atas barang dan/atau jasa yang digunakan; e) Hak untuk mendapatkan advokasi, perlindungan, dan upaya penyelesaian sengketa perlindungan konsumen secara patut; f) Hak untuk mendapat pembinaan dan pendidikan konsumen; g) Hak untuk diperlakukan atau dilayani secara benar dan jujur serta tidak diskriminatif; h) Hak untuk mendapatkan kompensasi, ganti rugi dan/atau penggantian, apabila barang dan/atau jasa yang diterima tidak sesuai dengan perjanjian atau tidak sebagaimana mestinya; dan i) Hak-hak yang diatur dalam ketentuan peraturan perundang-undangan.

Dalam pasal 4 terdapat hak-hak konsumen yang harus dilindungi hukum, apabila konsumen mendapat perlakuan perbuatan wanprestasi dari penjual seperti pelanggaran keamanan dan keselamatan barang, penjual tidak mencantumkan informasi yang benar dari barang yang dijualnya, penjual tidak mendengar komplain dari pembeli karena penjual tidak ingin bertanggungjawab, penjual tidak mau ganti rugi terhadap barang yang tidak sesuai dengan perjanjian terhadap konsumen, maka penjual dapat menempuh jalur hukum yang diatur dalam pasal 38 dan 39 ayat (2) Undang-Undang Nomor 19 Tahun 2016 tentang ITE yang mengatakan bahwa selain penyelesaian gugatan perdata sebagaimana dimaksud pada ayat (1), para pihak dapat menyelesaikan sengketa melalui arbitrase atau lembaga penyelesaian sengketa alternatif lainnya sesuai dengan ketenuan peraturan perundang-undangan sedangkan menurut Undang-Undang Nomor 8 Tahun 1999 tentang perlindungan konsumen, penjual melakukan wanprestasi maka penyelesaian sengketanya diatur dalam pasal 47 dan pasal 48 tentang penyelesaian sengketa melalui pengadilan dan diluar pengadilan (Ainul Yaqin). Adapun pengaturan dari perlindungan konsumen dilakukan dengan:

1. Menciptakan sistem perlindungan konsumen yang mengandung unsur keterbukaan akses informasi, serta menjamin kepastian hukum.

2. Melindungi kepentingan konsumen pada khususnya dan kepentingan seluruh pelaku usaha.

3. Meningkatkan kualitas barang dan pelayanan jasa.

4. Memberikan perlindungan kepada konsumen dari praktik usaha yang menipu dan menyesatkan.

5. Memadukan penyelenggaraan, pengembangan dan pengaturan perlindungan konsumen dengan bidang-bidang perlindungan pada bidang-bidang lainnya.

Dalam pelaksanaan jual beli pelaku usaha memiliki kewajiban dalam pasal 7 Undang-Undang Perlindungan Konsumen yang berisi tentang: a) Beritikad baik dalam melakukan kegiatan usahanya; b) Memberikan informasi yang benar, jelas dan jujur mengenai kondisi dari jaminan barang dan/atau jasa serta memberi penjelasan penggunaan, perbaikan dan pemeliharaan; c) Memperlakukan atau melayani konsumen secara benar dan jujur serta tidak diskriminatif; d) Menjamin mutu barang dan/atau jasa yang diproduksi dan atau diperdagangkan berdasarkan ketentuan standar mutu barang dan/atau jasa yang berlaku; e) Memberi kesempatan kepada konsumen untuk menguji, dan/atau garansi atas barang yang dibuat dan/atau yang diperdagangkan; e) Memberi kompensasi, ganti rugi dan/atau penggantian atas kerugian akibat penggunaan,pemakaian dan pemanfaatan barang dan/atau jasa yang diperdagangkan; dan d) Memberi kompensasi,ganti rugi dan/atau penggantian apabila barang dan/atau jasa yang diterima atau dimanfaatkan tidak sesuai dengan perjanjian. 
Apabila hak konsumen tidak dipenuhi oleh pelaku usaha maka pelaku usaha memiliki kewajiban untuk bertanggung jawab seperti ganti rugi misalnya ganti rugi pengembalian uang apabila barang tidak sampai kepada pembeli, ganti rugi apabila barang pembeli rusak. Tetapi sekarang banyak pelaku usaha yang tidak memenuhi kewajibannya seperti pasal diatas. Maka pembeli dapat menempuh jalur hukum untuk menyelesaikan perbuatan pelaku usaha tersebut.

Pelaksanaan jual beli pelaku usaha memiliki larangan yang diatur dalam Pasal 8 Undang-Undang perlindungan konsumen yang berisi tentang:

(1) Pelaku usaha dilarang memproduksi dan/atau memperdagangkan barang dan/atau jasa yang: a) Tidak memenuhi atau tidak sesuai dengan standar yang dipersyaratkan dan ketentuan peraturan perundang-undangan; b) Tidak sesuai dengan berat bersih, isi bersih, atau netto dan jumlah dalam hitungan sebagaimana yang dinyatakan dalam label atau etiket barang tersebut; c) Tidak sesuai dengan ukuran, takaran, timbangan dan jumlah dalam hitungan menurut ukuran yang sebenarnya; d) Tidak sesuai dengan kondisi, jaminan, keistimewaan atau kemajuan sebagaimana dinyatakan dalam label, etiket atau keterangan barang dan/atau jasa tersebut; e) Tidak sesuai dengan mutu, tingkatan, komposisi, proses pengolahan, gaya, mode atau penggunaan tertentu sebagaimana dinyatakan dalam label atau keterangan barang dan/atau jasa tersebut; f) Tidak sesuai dengan janji yang dinyatakan dalam label, etiket, keterangan, iklan atau promosi penjualan barang dan/atau jasa tersebut; g) Tidak mencantumkan tanggal kadaluarsa atau jangka waktu penggunaan/ pemanfaatan yang paling baik atas barang tertentu; h) Tidak mengikuti ketentuan berproduksi secara halal, sebagaimana pernyataan "halal" yang dicantumkan dalam label; i) Tidak memasang label atau membuat penjelasan barang yang memuat nama barang, ukuran, berat/isi bersih atau netto, komposisi, aturan pakai, tanggal pembuatan, akibat sampingan, nama dan alamat pelaku usaha serta keterangan lain untuk penggunaan yang menurut ketentuan harus dipasang atau dibuat; dan j) Tidak mencantumkan informasi dan/atau petunjuk penggunaan barang dalam bahasa indonesia sesuai dengan ketentuan perundang-undangan yang berlaku.

(2) Pelaku usaha dilarang memperdagangkan barang yang rusak, cacat atau bekas, dan tercemar tanpa memberikan informasi secara lengkap dan benar atas barang yang dimaksud.

(3) Pelaku usaha dilarang memperdagangkan sediaan farmasi dan pangan yang rusak, cacat atau bekas dan tercemar, dengan atau tanpa memberikan informasi secara lengkap dan benar.

(4) Pelaku usaha yang melakukan pelanggaran pada ayat (1) dan ayat (2) dilarang memperdagangkan barang dan/atau jasa tersebut serta wajib menariknya dari peredaran.

Pelaku usaha memiliki tanggungjawab yang telah diatur dalam Pasal 19 yang mengatakan bahwa: 1) Pelaku usaha bertanggung jawab memberikan ganti rugi atas kerusakan, pencemaran dan/atau kerugian konsumen akibat mengkonsumsi barang dan/atau jasa yang dihasilkan atau diperdagangkan; 2) Ganti rugi sebagaimana dimaksud pada Ayat (1) dapat berupa pengembalian uang atau penggantian barang dan/atau jasa yang sejenis atau setara nilainya, atau perawatan kesehatan dan/atau pemberian santunan yang sesuai dengan ketentuan peraturan perundang-undangan yang berlaku; 3) Pemberian ganti rugi dilaksanakan dalam tenggang waktu 7 (tujuh) hari setelah tanggal transaksi; 4) Pemberian ganti rugi sebagaimana dimaksud pada ayat (1) dan ayat (2) tidak menghapuskan kemungkinan adanya tuntutan pidana E-ISSN: 2657-0300 Lembaga Penelitian dan Penerbitan Hasil Penelitian Ensiklopedia $\quad 127$ 
berdasarkan pembuktian lebih lanjut mengenai adanya unsur kesalahan; dan 5) Ketentuan sebagaimana dimaksud dapa ayat (1) dan ayat (2) tidak berlaku apabila pelaku usaha dapat membuktikan bahwa kesalahan tersebut merupakan kesalahan konsumen.

Untuk itu pelaku usaha bertanggung jawab atas barang dan/atau jasa yang diperjual belikan kepada konsumen. Karena tanggung jawab hukum merupakan kewajiban menanggung sesuatu akibat menurut ketentuan hukum berlaku. Perlindungan hukum sangat perlu dalam pelaksanaan jual beli melalui e-commerce karena sekarang sangat banyak terjadi perbuatan yang melanggar hukum dalam pelaksaan jual beli online. Berdasarkan beberapa kelebihan dan kelamahan jual beli online dan jual beli konvensional yang dijelaskan dalam jual beli konvensional pembeli bisa mendapatkan barang yang diinginkan sedangkan dalam jual beli online pembeli tidak bisa mendapatkan barang yang diinginkan seperti warna barang tidak sesuai dengan gambar, pelayanan konsumen dapat dilakukan dengan mudah seperti tuntutan konsumen dapat diselesaikan secara langsung sedangkan melalui online penyelesaian tuntutan pembeli tidak bisa diselesaikan secara langsung, karena penjual dan pembeli tidak bertatap muka secara langsung dan pembayaran melalui jual beli konvensional lebih aman dibandingkan dengan jual beli online, dalam jual beli konvensional pembeli melakukan pembayaran dengan cas, agar terhindar dari penipuan dan tidak perlu khawatir sedangkan jual beli online pembayarannya dilakukan dengan pengiriman elektronik, jadi sangat rentan terjadinya penipuan. Menurut kelebihan dan kelemahan diatas, maka dapat diambil kesimpulan lebih banyak terjadinya wanprestasi melalui jual beli online. Karena Undang-undangnya belum mampu untuk mengcover semua jual beli online maka pelaksanaan jual beli online ini lebih rentan terjadinya perbuatan wanprestasi (https://www.jurnal.id).

Berdasarkan Undang-Undang Nomor 19 Tahun 2016 tentang ITE dan UndangUndang Nomor 8 Tahun 1999 tentang Perlindungan Konsumen penyelesaian sengketa jual beli online dan jual beli konvensional cara penyelesaiannya sengketanya samasama melalui perdata serta cara litigasi dan non litigasi. Untuk itu agar pembeli terhindar dari perbuatan wanprestasi maka pembeli harus jeli dan memastikan informasi tentang pelaku usaha sebelum melakukan jual beli online perlu dipastikan informasi tentang pelaku usaha seperti mencantumkan logo pelaku usaha dan mencantumkan alamat.

\section{Penutup}

Persyaratan perjanjian jual beli online melalui e-commerce masih memakai ketentuan Pasal 1320 KUHPerdata yang berisi tentang syarat sah perjanjian yaitu adanya kesepakatan kedua belah pihak, adanya kecakapan bertindak, adanya objek perjanjian dan adanya causa yang yang halal. Jadi pelaksanaan perjanjian jual beli online melalui e-commerce masih berlaku ketentuan syarat sah perjanjian dalam KUHPerdata. Bentuk perlindungan hukum terhadap pembeli dalam pelaksanaan perjanjian jual beli online melalui e-commerce jika penjual melakukan wanprestasi, maka bentuk penyelesaiannya diatur dalam pasal 38 Undang-Undang ITE dan Pasal 45 Undang-Undang perlindungan konsumen dilindungi dengan Undang-Undang Nomor 8 Tahun 1999 tentang perlindungan konsumen. Berdasarkan beberapa kelebihan dan kelamahan jual beli online dan jual beli konvensional diatas maka dapat disimpulkan bahwa banyak terjadinya wanprestasi melalui jual beli online. Karena Undang- 
undangnya belum mampu untuk mengcover semua jual beli online maka pelaksanaan jual beli online ini lebih rentan terjadinya perbuatan wanprestasi. Maka untuk itu perlu dibuat Undang-undang yang mengatur tentang pelaksanaan jual beli online.

\section{Daftar Pustaka}

Ahmad Miru dan Sutarman Yodo, Hukum Perlindungan Konsumen Rajawali Pers, Jakarta, 2017.

Amirudin dan Zainal Asikin, Pengantar Metode Penelitian Hukum, PT. Raja Grafindo Persada, Jakarta, 2016.

Ashshofa,Burhan, Metode Penelitian Hukum, Rineka Cipta, Jakarta, 1996.

Celina Tri Siwi Kristiyanti, Hukum Perlindungan Konsumen, Sinar Grafika, Jakarta, 2017.

Dewi,Shinta,Cyberlaw Perlindungan Privasi atas Informasi Pribadi, Widya Padjadjaran, Bandung, 2009.H.M. Arsyad Sanusi, Hukum E-commerce, Sasrawarna Printing, Jakarta Pusat, 2011.

I Ketut Oka Setiawan, Hukum Perikatan, Sinar Grafika, Jakarta,2016.

J. Satrio, Wanprestasi Menurut KUHPerdata, Doktrin, dan Yurisprudensi, PT. Citra Aditya Bakti, Bandung, 2014.

K. M. Yahya Harahap, , Segi-Segi Hukum Perjanjian, Bandung, Alumni,2006.

Muhammad,Abdulkadir, Hukum Perdata Indonesia, PT. Citra Aditya Bakti, Bandung, 2010.

Projodikoro,Wirjono, Hukum Perdata Tentang Persetujuan-persetujuan Tertentu, Bandung:sumur, 1991.

Raditio,Resa, Aspek Hukum Transaksi Elektronik, Yogyakarta: Graha Ilmu, 2014.

Suparni,Niniek, Cyberspace Problematika \& Antisipasi PengaturanNya, Sinar Grafika, Jakarta, 2009.

Santiago,Faisal, Pengantar Hukum Bisnis, Mitra Wacana Media, Jakarta, 2012.

Sjahputra,Iman, Perlindungan Konsumen dalam Transaksi Elektronik, PT. Alumni, Bandung, 2010.

Sidabalok,Janus, Hukum Perlindungan Konsumen di Indonesia,Ctk.PT.Citra Aditya Bakti, Bandung, 2014.

Salim, Pengantar Hukum Perdata Tertulis (BW), Sinar Grafika, Jakarta, 2002.

Sunarso,Siswanto, Hukum Informasi Dan Transaksi Elektronik, Rineka Cipta, Jakarta, 2009.

Soekanto,Soerjono, Penelitian Hukum Normatif Suatu Tinjauan Singkat, Rajawali Pers, Jakarta, 2009.

Suharnoko, Hukum Perjanjian Teori dan Analisa Kasus, Kencana,Jakarta, 2004.

Sutekti dan Galang taufani, 2018, Metode Penelitian Hukum (Filsafat, Teori dan Praktik), PT.Raja Grafindo Persada, Depok

Subekti R, H, Hukum Perjanjian, Jakarta, Intermasa, Hlm.64

Umar Said Sugiarto, Pengantar Hukum Indonesia, Sinar Grafika,Jakarta, 2015.

Zulham, Hukum Perlindungan Konsumen, Kencana Prenada Media Group, Jakarta, 2013.

Andi Tentri Ajeng P, 2017, "Tinjauan Hukum Perjanjian Jual Beli Melalui Ecommerce",http://repositori.uinalauddin.ac.id/4229/1Andi\%20Tenri\%Ajeng\%.pd $\mathrm{f}$

Dhea Handariningtyas, 2017,"Transaksi Jual Beli Melalui Media Instragram Menurut Undang-Undang Nomor 11 Tahun 2008 Tentang Informasi dan Transaksi 
Vol. 2 No.2 Juni 2020

Ensiklopedia Social Review

http://jurnal.ensiklopediaku.org

\section{Elektronik",}

http://digilib.unila.ac.id/26207/3skripsi\%20tanpa\%20bab\%20pembahasan.pdf,a

Edi suryadi, 2018,"Penggunaan Sosial Media Whatsapp", Nomor.1 April, Vol.07, https://jurnal.staialhidayahbogor.ac.id/index.php/ei/article/download/211/227.pdf

Herniwati, 2015, "Penerapan Pasal 1320 KUHPerdata terhadap Jual Beli Secara Online (E-commerce), Volume 8.i4, http://garuda.ristekbrin.go.id/documents/detail/854303.pdf.

Hillary Ayu Sekar Gusti, 2018, "Wanprestasi Penjual Dalam Perjanjian Jual Beli ECommerce”,https://dspace.uii.ac.id/bitstream/handle/123456789/11866/Whole\% 20Skripsi\%20Print\%20Hard\%20Cover.pdf.

Moh. Zainol Arief \& Sutrisni, 2014, "Perbuatan Melawan Hukum dalam Transaksi Jual Beli melalui Internet di Tinjau dari Buku III KUHPerdata”, Nomor.2Vol.1 ,https://media.neliti.com/media/publication/135649-ID-perbuatan-melawanhukum-dalam-transaksi.pdf.

Nandang Strurisno, 2001, "Cyberlaw : Problem dan Prospek Pengaturan AktivitasInternet",Nomor1,1Juni2013Vol.XV,https://www.researchgate.net/publi cation/307613122CyberlawProblemdanProspekPengaturanAktifitasInternet.pdf.

Lia Catur Muliastuti, 2010, "Perlindungan Hukum Bagi Para Pihak dalam Perjanjian Jual Beli melalui Media Internet”, diakses pada tanggal 09 Maret 2020 pukul 19.17 WIB

Rahmayani Indrasari, 2018, "Pelaksanaan Jual Beli Online (e-commerce) Pada Online Shop Monstreation”, Vol V Edisi https://jom.unri.ac.id/index.php/JOMFHUKUM/article/download/23203/22465,p df.

Rita Wahyuni Arifin. 2015, "Peran Facebook sebagai Media Promosi dalam Mengembangkan Industri Kreatif". Nomor 2. Vol.2, diakses pada tanggal 21 Desember 2019 Pukul 12.28 WIB

Rina Sari Nasution, 2017, "Hukum Peralihan Resiko dalam Jual Beli Pada Online Shop (Belz Shop) Menurut Wabbah Zuhaily, http://repository.uinsu.ac.id/2817/1/SKRIPSI_Rina_Sari_Muamalah_A.pdf.

Sanawiah \& Muhammad Zainul, 2018, "Batasan Kedewasaan dan Kecakapan Hukum pewasiat Menurut Hukum Islam Dan Hukum KUHPerdata", Volume 5 lssue 1 , diakses pada tanggal 12 Maret 2020 pukul 14.20 WIB

Setia Putra, 2014, "Perlindungan Hukum terhadap Konsumen dalam Transaksi Jual Beli melalui E-commerce", Nomor 2, Vol. 4, http://media.neliti.com/media/publications/9164-ID-perlindungan-hukumterhadap-konsumen-dalam-transaksi-jual-beli-melalui-e-commerce,pdf.

Tira Nur Fitria, 2017, “Bisnis Jual Beli Online (Online Shop) dalam Hukum Islam dan Hukum Negara", Nomor 01 Maret Vol. 03, https://jurnal.stieaas.ac.id/index.php/jei/article/view/99.pdf.

http://repository.unsada.ac.id/780/2/BAB\%20I.pdf. Pengaruh Gaya Hidup dan Persepsi Risiko terhadap Minat Beli di Media sosial Instagram.

https://www.researchgate.net/publication/312352400.pdf. Penerapan Pasal 1320 KUHPerdata terhadap Jual Beli secara Online (e-commerce) https://m.hukumonline.com/berita/baca/lt5a27cbecc0fd8/saatnya-mengingat-kembalialat-alat-bukti-dalam-perkara-perdata/ 
https://m.hukumonline.com/klinik/detail/ulasan/cl5461/syarat-dan-kekuatan-hukumalat- bukti-elektronik/

H. Bahiyah, 2016, Jual Beli dalam Hukum islam dan Hukum Perdata, http://digilib.uinsby.ac.id/12989/23/Bab\%202.pdf

I. http//digilib.unila.ac.id/6225/13/BAB\%2011.pdf Pengertian Perlindungan Hukum 